\title{
Kissing Christians
}


DIVINATIONS: REREADING LATE

ANCIENT RELIGION

Series Editors

Daniel Boyarin

Virginia Burrus

Charlotte Fonrobert

Robert Gregg

A complete list of books in the series

is available from the publisher 


\title{
Kissing Christians \\ Ritual and Community in the Late Ancient Church
}

\author{
Michael Philip Penn
}

\author{
$\overline{\text { PENN }}$ \\ UNIVERSITY OF PENNSYLVANIA PRESS \\ Philadelphia
}




\title{
Copyright (C) 2005 University of Pennsylvania Press All rights reserved \\ Printed in the United States of America on acid-free paper
}

\author{
I0 $\quad \begin{array}{lllllllll}9 & 8 & 7 & 6 & 5 & 4 & 3 & 2 & 1\end{array}$ \\ Published by \\ University of Pennsylvania Press \\ Philadelphia, Pennsylvania 19104-401 \\ Library of Congress Cataloging-in-Publication Data
}

Penn, Michael Philip.

Kissing Christians : ritual and community in the late ancient church / Michael Philip Penn.

p. cm. - (Divinations)

Includes bibliographical references (p. )and index.

ISBN o-8122-3880-X (cloth : alk. paper)

I. Kissing-Religious aspects-Christianity. 2. Worship-History-Early church, ca. 30-600. 3. Church history. I. Title. II. Series

BVi97.K57 $\mathrm{P}_{46} 2005$

270. - dc22

2005042223 


$$
\begin{gathered}
\text { To Dirk, Carol, and Starfire } \\
\text { for teaching me about true community }
\end{gathered}
$$


